\title{
Peran Pekerja Perempuan Dalam Memenuhi Ekonomi Keluarga: Dari Peran Domestik Menuju Sektor Publik
}

\author{
Darmin Tuwu \\ Ilmu Kesejahteraan Sosial Fakultas Ilmu Sosial dan Ilmu Politik Universitas Haluoleo \\ Kendari, Indonesia \\ darmintuwu@gmail.com
}

\begin{abstract}
This paper aims to elaborate the extent of women's role working in the informal sector at marine tourism area in Batu Gong Beach of Konawe District. This research is a qualitative research using case study approach. The data was collected using in-depth interviews, Focus Group Discussion, and observation. Interviews were conducted on 15 women who had been married and have children, who worked as rice sellers, gogos, burasa, sate pokea, beverages, cakes, candies, cigarettes, tire rentals for swimming equipment, rental mats for seat, etc. The results indicate that the role of women who work and have income play significant role to support the family finance. The income earned from selling is used to meet the needs of household life such as: as the complementary of the husband and family income; for daily shopping needs; for school's fee and children's expenses; and for other important needs such as when it comes to crises, severe illness, and other family problems. This study is expected to be useful for scientific development in the theme of the role of women who work in creating a prosperous family.
\end{abstract}

Keywords: roles; workers; women; family economy

\section{Abstrak}

Tulisan ini bertujuan untuk mengelaborasi sejauh mana peran perempuan pekerja sektor informal dalam memenuhi ekonomi keluarga di kawasan wisata Bahari Pantai Batu Gong di Kabupaten Konawe. Penelitian ini merupakan penelitian kualitatif dengan menggunakan pendekatan studi kasus. Metode pengumpulan data melalui wawancara mendalam, Focus Group Discussion, dan observasi. Wawancara dilakukan terhadap 15 orang perempuan yang telah berkeluarga dan memiiki anak, yang bekerja sebagai penjual nasi bungkus, gogos, burasa, sate pokea, aneka minuman, aneka kue, permen, rokok, penyewaan ban dalam untuk alat berenang, penyewaan tikar, dll. Hasil penelitian menunjukkan bahwa peran perempuan desa yang bekerja di kawasan pariwisata pantai Batu Gong sangat besar dalam mendukung pemenuhan ekonomi keluarga. Pendapatan yang diperoleh dari hasil usaha tersebut kemudian mereka gunakan untuk memenuhi kebutuhan hidup rumah tangga seperti; Pertama, untuk menambah penghasilan suami dan pendapatan keluarga; Kedua, untuk keperluan belanja keluarga sehari-hari; Ketiga, untuk keperluan biaya sekolah anak-anak; dan keempat, sebagian pendapatan ditabung untuk keperluan penting lainnya seperti ketika mengalami krisis, sakit keras, dan masalah keluarga lainnya. Hasil penelitian ini diharapkan dapat berguna bagi pengembangan keilmuan dalam tema peran perempuan yang bekerja dalam menciptakan keluarga sejahtera.

Kata kunci: peran; pekerja; perempuan; ekonomi keluarga

\section{A. Pendahuluan}

Aktivitas domestik sudah sejak lama dilekatkan pada perempuan. Asosiasi dua hal tersebut bahkan sudah ada jauh sebelum kebanyakan perempuan lahir. Hal itu kemudian 
menjadi budaya dan adat istiadat. Perempuan selalu dikonotasikan sebagai manusia pekerja domestik (homemaker) yang dinilai tidak dapat berkontribusi secara aktif di luar rumah sehingga perannya tidak lebih dari sekadar aktivitas dalam rumah. Di kemudian hari, terutama di dunia kerja, banyak posisi strategis yang aksesnya tertutup bagi perempuan. Perempuan dianggap tidak pantas memimpin dalam pekerjaan karena dinilai sebagai makhluk yang terlalu menggunakan perasaan dan sulit mengambil keputusan dengan bijak. Pelekatan pembagian pekerjaan antara perempuan dan laki-laki sudah sejak lama diyakini kebenarannya. Perempuan selalu dikaitkan dengan beberapa kata, "sumur, dapur, kasur" yang hingga kini digugat eksistensinya. Wacana tersebut dinilai sebagai wacana usang yang tidak dapat dibuktikan secara nyata karena banyak perempuan yang juga mengambil bagian penting di ranah produktif. Walaupun pada tataran kenyataan, secara mendalam perempuan masih terus dilekatkan dengan "sumur, dapur dan kasur" dan belum mampu keluar secara utuh tanpa tendensi apapun.

Peran perempuan secara tradisional masih dialamatkan pada kegiatan non-ekonomi, yaitu peran perempuan sebagai pengasuh anak dan mengurus rumah tangga, namun kenyataannya tidaklah demikian. Seiring dengan perkembangan masyarakat yang semakin kompleks, maka peran perempuan pun turun bergeser. Zaman dahulu kaum lelaki berperan sebagai pencari nafkah (publik), sementara kaum perempuan tinggal di rumah mengurus urusan domestik. Tetapi dewasa ini zaman telah berubah. Tidak hanya kaum lelaki yang berkiprah di ranah publik, namun kaum perempuan juga telah berperan dalam kegiatan ekonomi dan publik. Peran serta kaum perempuan dalam kegiatan ekonomi rumah tangga merupakan fenomena umum yang telah berlangsung dalam kurun waktu yang lama dan menjangkau seluruh sistem sosial-ekonomi masyarakat. Hal ini menunjukkan bahwa perempuan tidak hanya berperan serta dalam sektor domestik rumah tangga, tetapi juga berperan dalam sektor ekonomi dan publik. Dalam banyak literatur dijumpai bahwa perempuan yang bekerja di sektor publik selalu dikaitkan dengan keadaan ekonomi rumah tangga pekerja perempuan. Salah satu alasannya adalah alasan ekonomi dan masalah kemiskinan. Masalah kemiskinan merupakan persoalan global. Sayogyo ${ }^{1}$ mengatakan bahwa persoalan kemiskinan sudah berlangsung sejak zaman penjajahan sampai zaman pembangunan. Persoalan tersebut hingga kini belum tuntas dan bahkan semakin sengit diperbincangkan. Tidak hanya di kota-kota besar tetapi juga sampai ke desa-desa.

Di perdesaan, bidang pertanian merupakan bidang di mana kaum perempuan dapat terlibat secara intensif dan berperan penting di dalam keseluruhan proses transformasi dan perkembangan masyarakat perdesaan. Menurut Suratiyah, $\mathrm{dkk}^{2}$ kaum perempuan perdesaan bukan saja merupakan penentu tradisi bercocok tanam, tetapi fakta menunjukkan bahwa pada saat suami tidak ada di rumah, maka perempuanlah yang mengelola berbagai kegiatan ekonomi keluarga.

Dewasa ini telah terjadi pergeseran peran serta kaum perempuan perdesaan di bidang ekonomi, terutama perubahan kesempatan kerja yang dipengaruhi oleh proses pembangunan pertanian. Masuknya program revolusi hijau dan komersialisasi pertanian merupakan tekanan penting yang dapat merubah institusi sosial (social institution) yang terdapat pada masyarakat perdesaan, dari penggunaan alat-alat tradisional berubah

\footnotetext{
1 Sayogyo, "Pemikiran tentang Kemiskinan di Indonesia: Dari Masa Penjajahan Sampai Masa Pembangunan", Prisma: Majalah Pemikiran Politik, Sosial dan Ekonomi. Nomor 3, (Tahun XII, 1993), h.3.

${ }^{2}$ Ken, Suratiyah, dkk, Dilema Wanita Antara Industri Rumah Tangga dan Aktivitas Domestik, (Yogyakarta: Aditya Media, 1996), h. 38.
} 
menjadi penggunaan alat-alat modern atau yang lebih dikenal dengan sebutan modernisasi pertanian. Sebagai contoh misalnya ani-ani yang telah digantikan oleh sabit atau arit untuk memanen padi, lesung yang telah digantikan fungsinya oleh mesin penggiling padi. Transformasi tersebut telah mengurangi kesempatan kerja dan membatasi peran serta perempuan dalam kegiatan pertanian ${ }^{3}$.

Berkurangnya kesempatan kerja kaum perempuan yang berstatus sebagai isteri atau ibu rumah tangga di sektor pertanian tidak secara langsung menyebabkan perempuan kehilangan lapangan pekerjaan, namun peluang kerja perempuan masih banyak terdapat pilihan-pilihan pekerjaan lain di luar sektor pertanian. Aneka peluang kerja perempuan di luar sektor pertanian dapat memberikan kemandirian dan produktivitas ekonomi yang lebih besar, seperti pada bidang perdagangan, kerajinan, sektor jasa, perikanan, bidang pariwisata, dan sebagainya. Beragamnya lapangan pekerjaan yang dapat memberikan peluang, kesempatan, dan kemandirian kaum perempuan dalam bekerja adalah salah satu dampak dari komersialisasi di bidang pertanian yang memunculkan bentuk-bentuk lapangan pekerjaan baru yang pada masa lalu tidak ditemukan di wilayah perdesaan ${ }^{4}$.

Dekade terakhir, kiprah perempuan di ranah produktif mulai menunjukkan eksistensinya. Bisa kita lihat bagaimana perempuan dilibatkan secara aktif bekerja di semua lini. Mulai dari bidang ekonomi, sosial, politik hingga agama. Semua lini telah dapat mengandalkan perempuan sebagai sumber daya manusia yang produktif dan andal. Meski demikian, toh, banyak hal yang masih membelenggu perempuan dalam kiprahnya di ranah produktif. Perempuan masih saja terbelenggu dengan budaya, mitos dan jauh dari kata kompetensi yang sehat di ranah produktif. Banyak anggapan perempuan yang bekerja di ranah produktif akan lebih kesulitan mengambil kebijakan ketimbang laki-laki, sekalipun kompetensinya melampaui laki-laki. Begitu pula dari sisi agama, perempuan pemimpin hingga saat ini masih dianggap tabu dan menyalahi kodrat.

Kaum perempuan desa yang tinggal di kawasan pariwisata Kabupaten Konawe, telah lama menekuni pekerjaan, mereka tidak hanya bekerja di sektor pertanian tetapi juga bekerja di luar sektor ekonomi produktif dengan bekerja pada sektor informal sebagai penjual makanan dan minuman serta memberikan pelayanan jasa terhadap para wisatawan yang berkunjung di kawasan wisata Pantai Bahari Batu Gong. Dibandingkan desa-desa lain di Kecamatan Bondoala, Desa Lalimbue merupakan salah satu desa yang memiliki angkatan kerja wanita yang cukup banyak. Jumlah angkatan kerja wanita Lalimbue terus bertambah dari tahun ke tahun. Menurut Data Kantor Desa Lalimbue Tahun 2017, terdapat 297 orang angkatan kerja wanita atau sepertiga dari perbandingan jumlah penduduk laki-laki. Mereka umumnya bekerja atau mengelola usaha ekonomi kecil seperti perdagangan, rumah makan, penginapan, perikanan, dan sektor jasa lainnya. Peluang-peluang pengembangan usaha ekonomi kecil perempuan ibu rumah tangga tersebut, dapat memberikan nilai tambah serta dapat menambah pendapatan ekonomi keluarga.

Bekerjanya kaum perempuan di sektor publik yang berdampak pada peningkatan pendapatan ekonomi keluarga, sebagai akibat dari isteri dan ibu rumah tangga yang

\footnotetext{
${ }^{3}$ Sajogyo, Pudjiwati, Peranan Wanita Dalam Pembangunan Masyarakat Desa, (Jakarta: Rajawali Pers, 1983), h. 69.

${ }^{4}$ Sebelum revolusi hijau terjadi, lapangan pekerjaan yang tersedia dan dapat dimasuki oleh kaum perempuan di wilayah perdesaan hanyalah di bidang pertanian. Namun setelah revolusi hijau, banyak lapangan pekerjaan yang bisa dimasuki oleh kaum perempuan, seperti bidang perdagangan, kerajinan, sektor jasa, perikanan, bidang pariwisata, dll.
} 
bekerja, dari sisi sosial ekonomi merupakan faktor yang dapat mengurangi dominasi kaum lelaki terhadap kaum perempuan dalam kehidupan keluarga. Namun dalam perspektif sosial budaya, bekerjanya perempuan di sektor publik tidak secara serta merta merobohkan dominasi kaum lelaki terhadap kaum perempuan yang menganut sistem patriarki, karena masih ada hambatan-hambatan sosio-kultural yang harus dilewati.

Penelitian kualitatif dengan pendekatan studi kasus ${ }^{5}$ ini dilakukan di kawasan Wisata Bahari Pantai Batu Gong di Kabupaten Konawe Provinsi Sulawesi Tenggara. Pemilihan lokasi ini berdasarkan pertimbangan bahwa di lokasi ini banyak perempuan yang berstatus sebagai isteri dan ibu rumah tangga yang mengembangkan usaha ekonomi kecil seperti membuka warung-warung makanan dan minuman, penjual gogos dan pokea, dan menyediakan pelayanan jasa bagi pengunjung wisata pantai. Teknik penentuan informan berdasarkan snowball sampling yaitu teknik penentuan informan yang semula jumlahnya kecil, kemudian membesar ${ }^{6}$. Kriteria informan penelitian adalah perempuan yang berstatus sebagai isteri dan ibu rumah tangga serta bekerja atau mempunyai usaha ekonomi kecil seperti membuka warung-warung makanan dan minuman, penjual gogos dan pokea, serta penyedia layanan jasa bagi pengunjung wisata pantai.

Tulisan ini bertujuan untuk mengelaborasi bagaimana peran perempuan yang bekerja di sektor publik, dan faktor-faktor apa saja yang menghambat perempuan yang bekerja dalam memenuhi ekonomi keluarga di kawasan pariwisata Bahari Pantai Batu Gong Kabupaten Konawe, khususnya di Desa Lalimbue Kecamatan Bondoala.

\section{B. Peran Perempuan}

Peran perempuan dalam ranah domestik sangat penting namun tidak ada jaminan serta penghargaan dalam bentuk materi. Perempuan memberikan kesempatan yang lebih kepada laki-laki dalam melakukan kegiatan ekonomi. Laki-laki menjadi satu-satunya agen ekonomi tempat perempuan bergantung secara finansial. Ini menggambarkan bagaimana perempuan dalam rumah tangga bekerja dari pagi sampai malam tetapi tidak dibayar. Bahkan segala status sosial dan ekonominya selalu mengikuti suaminya, bukan pencapaian sendiri.

Kesselmen dan kawan-kawan ${ }^{7}$ mengatakan bahwa pekerjaan rumah tangga yang dilakukan oleh perempuan sangat menguras tenaga dan waktu. Pekerjaan rumah tangga bahkan dilakukan sebelum matahari terbit. Ketika anak-anak pergi ke sekolah dan suami bekerja, perempuan kembali dihadapkan pada pekerjaan rumah tangga yang tak kunjung usai. Anak dan suami pulang, mereka perlu disiapkan makanan. Bahkan ketika malam, perempuan masih harus mendampingi anaknya belajar kemudian melayani suaminya. Pekerjaan perempuan di ranah domestik menguras tenaga, waktu dan membutuhkan keterampilan. Sementara itu, keterlibatan peran laki-laki dalam kegiatan domestik masih sangat jarang, sebab kebanyakan laki-laki diasosiasikan dalam peran mencari nafkah saja.

Studi perempuan yang mengkaji relasi gender di berbagai masyarakat dunia, pada umumnya sependapat bahwa terjadi ketidakadilan dalam hubunggan gender. Mansour

\footnotetext{
${ }^{5}$ Robert K. Yin, Studi Kasus: Desain dan Metode, (Jakarta: PT. RajaGrafindo Persada, 2008), hlm. 29. hlm. 85

${ }^{6}$ Sugiyono, Metode Penelitian Kuantitatif Kualitatif Dan $R \&$ D, (Bandung: Penerbit Alfabeta, 2007),

${ }^{7}$ Kesselmen, Amy dkk, Women Images and Realities, A Multicultural Anthology, Second Edition, (California: Mayfield Publishing Company, 1999), h. 188.
} 
Fakih $^{8}$ menjelaskan bahwa ada enam ketidakadilan gender yang terjadi pada perempuan, yaitu (1) marjinalisasi atau proses pemiskinan ekonomi pada perempuan; (2) subordinasi atau anggapan tidak penting dalam keputusan politik; (3) pembentukan stereotipe perempuan atau melalui pelabelan negatif; (4) kekerasan (violence) terhadap perempuan, (5) beban kerja tidak proporsional, beban kerja lebih panjang dan lebih banyak (burden), serta (6) sosialisasi ideologi nilai peran gender.

Saptari dan Holzner Brigitte ${ }^{9}$ mengatakan bahwa teori sosial telah digunakan untuk menjelaskan posisi subordinat perempuan dalam relasi gender tersebut, seperti teori materialisme historis Karl Marx dan Engel. Teori-teori materialisme historis Karl Marx menekankan adanya sifat-sifat universal dalam menjelaskan posisi subordinat kaum perempuan. Bahwa perempuan meskipun mereka bekerja sepanjang hari dari waktu subuh hingga malam hari, yang mengerjakan berbagai jenis pekerjaan rumah tangga seperti memasak, mencuci, membersihkan rumah, merawat dan mendidik anak, melayani suami, dll, namun tetap saja pekerjaan domestik kaum perempuan tidak dihitung karena tidak menghasilkan uang secara ekonomi. Padahal pekerjaan yang dilakukan oleh perempuan tersebut sangat berat. Teori-teori sosial ini mengalami kritikan karena menganggap bahwa posisi subordinat kaum perempuan berlaku untuk semua masyarakat dan kebudayaan di dunia.

Pelekatan (streotyping) perempuan dengan pekerjaan domestik masih menjadi cara yang paling ampuh untuk melanggengkan ideologi patriarki. Manneke Budiman ${ }^{10}$ menyebutkan bahwa pekerjaan domestik tidak pernah dianggap sebagai sebuah pekerjaan. Pekerjaan domestik dianggap tidak menghasilkan uang dalam dimensi ekonomi sehingga membuat pekerjaan domestik bukan menjadi bagian pekerjaan produktif. Karena itu perempuan yang berkarya di ranah publik terus saja dibebani dengan tanggung jawab domestik seperti mengasuh anak, mengurus rumah, memasak, menyiapkan kebutuhan keluarga, membayar tagihan-tagihan dan masih banyak pekerjaan domestik lainnya. Serta harus mempertimbangkan berbagai persoalan keuangan, pendidikan, serta sosial maupun keharmonisan keluarga.

Perempuan yang memilih bekerja harus melakukan dua hal sekaligus, yaitu menjadi produktif dengan bekerja di ranah publik dan tetap mengurus urusan domestik. Hal ini akhirnya menimbulkan masalah baru yaitu perempuan terus saja bekerja untuk mengaktualisasikan dirinya, namun impiannya terbatas hanya bekerja saja dan menghasilkan pundi-pundi ekonomi agar mendapat penghargaan dan perlakuan yang lebih baik dari suami serta tidak menggantungkan hidupnya kepada laki-laki. Sedangkan cita-cita perempuan harus terkubur mati bersama tumpukan beban yang terus saja membuatnya mati perlahan. Candraningrum ${ }^{\mathbf{1 1}}$ menegaskan bahwa bila perempuan pulang ke rumah sehabis pekerjaan formalnya, maka ia akan mengerjakan tugas pekerjaan shift kedua di rumah. Ia menegaskan ini adalah takdir yang sangat tragis bagi perempuan, bukan dikarenakan perlawanan atau ketidaksukaan akan pekerjaan domestik, melainkan perempuan membutuhkan waktu untuk beristirahat, berefleksi dan menenun diri.

${ }^{8}$ Fakih, Mansour, Analisis Gender dan Transformasi Sosial, (Yogyakarta: Pustaka Pelajar Offset, 2007), h. 12-24.

${ }^{9}$ Saptari, Ratna, dan Holzner Brigitte, Perempuan Kerja dan Perubahan Sosial; Sebuah Pengantar Studi Perempuan, (Jakarta: Kalyanitra, 1997), h. 64-73.

${ }^{10}$ Budiman, Manneke, "Bapak Rumah Tangga: Menciptakan Kesetaraan atau Membangun Mitos Baru?", Jurnal Perempuan, Volume 18 No. 1, (Maret, 2013), h. 79-92.

${ }^{11}$ Candraningrum, Dewi, "Superwoman Syndrome dan Devaluasi Usia: Perempuan dalam Karier dan Rumah Tangga”, Jurnal Perempuan, Volume 18 No. 1, (Maret, 2014), h. 14. 


\section{Perempuan Pekerja}

Pada era tahun 1900-an, Raden Ajeng Kartini seolah berdiri kokoh sendirian melawan tradisi yang membatasi perempuan Jawa dalam mengakses pendidikan. Dalam perjuangannya, ia terus berbicara tentang keterlibatan perempuan dalam sektor publik. Baginya perempuan harus setara dengan laki-laki dalam kesempatan memperoleh akses pendidikan. Kartini yakin bahwa pendidikan mampu mengubah cara pandang masyarakat dan meningkatkan kualitas hidup perempuan. "Kartini memberontak terhadap feodalisme, poligami, dan adat istiadat yang mengukung perempuan. Dia yakin pemberian pendidikan yang lebih merata merupakan kunci kemajuan perempuan." Perempuan dapat memilih pekerjaan dan meningkatkan kapasitasnya untuk meniti jenjang karier lebih tinggi. Perempuan juga dapat memilih semua potensi, apa yang disukai dan apa yang tidak disukai. Kesempatan ini banyak digunakan oleh perempuan untuk mengaktualisasikan diri dalam ranah produktif. Perempuan telah resmi berkontribusi secara nyata dalam pembangunan, baik di bidang ekonomi, sosial dan politik. Namun, tidak sedikit pula perempuan bekerja karena terdesak tuntutan ekonomi dan bahkan menjadi tulang punggung keluarga.

Dewasa ini banyak perempuan yang bekerja, baik bekerja di luar rumah maupun bekerja dalam rumah. Perempuan banyak yang memimpikan bekerja dari rumah sembari tidak meninggalkan statusnya sebagai ibu rumah tangga. Hal ini dilakukan agar beban ganda yang melingkupi perempuan berkurang. Pekerjaan-pekerjaan tersebut menjadi idaman sebagian perempuan seperti, berdagang di rumah membuka toko atau kios, menjadi pengrajin, penjahit dan bahkan menulis.

Salah satu contoh kaum perempuan yang bekerja di luar rumah adalah perempuan yang bekerja sebagai pemecah batu suplit ${ }^{12}$ di Kecamatan Moramo Utara Kabupaten Konawe Selatan Provinsi Sulawesi Tenggara. Hasil penelitian Darmin Tuwu ${ }^{13}$ menemukan bahwa kondisi kaum perempuan yang bekerja sebagai pemecah batu suplit sangat memprihatinkan, disebabkan oleh upah kerja yang diterima sangat rendah, meskipun jam kerja relatif panjang dan penuh resiko. Kondisi tersebut membuat kaum perempuan pemecah batu suplit kesulitan untuk mengangkat harkat dan martabat, kesulitan meningkatkan kualitas kehidupan keluarga, sehingga mereka secara terus menerus berada dalam "kondisi kerentanan dari kemiskinan."

Berbeda dengan hasil penelitan Darmin Tuwu, Irwan Abdullah ${ }^{14}$ meneliti tentang perempuan yang bekerja di industri kerajinan dekat rumah. Ia menjelaskan bahwa ada empat keuntungan bekerja di industri kerajinan dekat rumah. Pertama, pekerjaan industri kerajinan memberikan kemungkinan bagi perempuan untuk menyelesaikan pekerjaan rumah tangga sehingga tidak mengganggu tugas rumah. Kedua, pekerjaan industri kerajinan dapat dilakukan tanpa harus meninggalkan kewajiban perempuan sebagai ibu karena pengasuhan anak tetap dapat dilakukan. Ketiga, industri kerajinan juga melibatkan anggota rumah tangga (terutama suami dan anak-anak) sehingga dapat

\footnotetext{
12 Batu suplit merupakan batu yang telah mengalami proses pemecahan dari ukuran awalnya besar (batu gelondongan) dirubah menjadi ukuran batu yang kecil-kecil. Ada tiga jenis ukuran batu suplit yaitu ukuran 12, 23, dan 57. Proses pemecahan batu besar menjadi batu ukuran kecil-kecil (batu suplit) tersebut dilakukan secara manual oleh ibu-ibu rumah tangga dengan menggunakan alat palu (martil).

${ }^{13}$ Tuwu, Darmin. "Studi Aspirasi Warga Komunitas Miskin Penambang Batu dan Pemecah Batu Suplit di Kecamatan Moramo Utara Kabupaten Konawe Selatan". Etnoreflika (Jurnal Sosial dan Budaya Jurusan Antropologi FIB UHO). Volume 4, Nomor 1. (Februari, 2015): hlm. 702-709.

${ }^{14}$ Irwan, Abdullah. Seks, Gender dan Reproduksi Kekuasaan, (Jogjakarta: Tarawang Press, 2001): 183-187.
} 
meringankan beban perempuan dalam menyelesaikan tugas-tugasnya sebagai pekerja. Keempat, penyelesaian tidak terikat pada waktu dan jam kerja sehingga dapat dikerjakan di sela-sela pekerjaan rumah tangga. Sayangnya usaha ini di dalam dimensi kultural ekonomi kita masih dianggap pekerjaan sampingan, bukan pekerjaan utama. Pekerjaan yang dilakukan dalam rumah masih diidentikkan dengan pekerjaan yang tujuannya membantu ekonomi keluarga, bukan menjadi pilihan ekonomi utama keluarga. Walaupun pendapatan yang diterima oleh perempuan yang terlibat dalam industri menurut Irwan Abdullah, memiliki arti penting dalam penghasilan rumah tangga. Walaupun banyak yang mengatakan bahwa pekerjaan kerajinan merupakan pekerjaan sampingan, justru kegiatan kerajinan memberikan upah yang lebih besar.

\section{Peran Perempuan Dalam Memenuhi Ekonomi Keluarga}

Peran perempuan dalam memenuhi ekonomi keluarga yang bekerja di kawasan wisata Bahari Pantai Batu Gong di Kabupaten Konawe, telah mengarah kepada persamaan peran dengan kaum laki-laki. Persamaan ini tidak lagi terbentur oleh belenggu sistem nilai sosiokultural, yaitu tidak lagi mengikuti pandangan tradisional yang menempatkan perempuan pada sektor domestik saja. Peran perempuan telah mengalami perkembangan tidak hanya identik dengan "sumur, dapur, dan kasur" tetapi telah memasuki ranah publik.

Keberadaan wisata Bahari Pantai Batu Gong memberikan kesempatan kerja, peluang usaha, kemandirian, dan produktivitas ekonomi yang lebih besar bagi kaum perempuan yang tinggal di lokasi ini. Dari 297 orang perempuan yang masuk dalam angkatan kerja, sebagian besar mereka terlibat dalam sektor publik dengan cara membuka usaha, berdagang aneka makanan dan minuman dan penyediaan berbagai layanan jasa bagi wisatawan. Aktivitas kaum perempuan dalam bidang ekonomi mempunyai relevansi yang signifikan terhadap upaya emansipasi perempuan, bahwa perempuan yang bekerja telah memberi kontribusi yang besar pada perekonomian keluarga. Pendapatan yang diperoleh oleh kaum perempuan yang bekerja setiap bulan bervariasi antara Rp. 500.000 sampai dengan Rp. 2.500.000. Perbedaan besaran pendapatan tersebut dipengaruhi oleh banyaknya pengunjung yang datang dan jenis pekerjaan yang mereka lakukan. Jam kerja mereka dari pagi hingga sore hari setiap hari. Namun pengunjung yang ramai adalah pada hari Sabtu, Minggu, dan hari-hari libur lainnya.

Meskipun pekerjaan yang dilakoni oleh para perempuan pekerja tersebut masih tergolong sebagai pekerjaan sampingan ${ }^{15}$ karena status kerja mereka membantu suami bekerja, dan untuk menambah pendapatan suami, namun hasilnya cukup signifikan dalam membantu penghasilan keluarga dan pemenuhan kebutuhan ekonomi rumah tangga sehari-hari. Suami-suami perempuan yang bekerja ini ada yang bekerja sebagai penjual, nelayan, petani, buruh tani, dan aneka pekerjaan serabutan lainnya yang mana penghasilannya juga pas-pasan. Melihat kondisi suami demikian, membuat para isteri bekerja memanfaatkan peluang yang ada di desa mereka tinggal, serta mengoptimalkan potensi dan kemampuan yang mereka miliki.

Peran perempuan dalam pemenuhan ekonomi keluarga yang bekerja di kawasan Pariwisata Bahari Pantai Batu Gong di Kabupaten Konawe Provinsi Sulawesi Tenggara,

15 Beberapa dari informan penelitian yang diwawancarai diketahui bahwa bagi perempuan yang berstatus sebagai "single parent" pekerjaan yang mereka lakukan tergolong sebagai pekerjaan utama, namun bagi perempuan yang masih bersuami pekerjaan yang mereka lakukan adalah tergolong "pekerjaan sampingan" karena membantu suami bekerja atau membantu memenuhi ekonomi keluarga. 
terwujud setelah kaum perempuan yang berstatus sebagai isteri dan ibu rumah tangga tersebut membuka usaha, bekerja, dan mengelola pekerjaan secara mandiri dan mempunyai pendapatan sendiri. Pendapatan yang diperoleh dari berusaha tersebut kemudian dimanfaatkan oleh perempuan yang bekerja tersebut untuk pemenuhan kebutuhan hidup rumah tangga seperti: Pertama, menambah penghasilan suami dan pendapatan keluarga; Kedua, untuk keperluan belanja keluarga sehari-hari; Ketiga, untuk keperluan biaya sekolah anak-anak; dan Terakhir, sebagian ditabung untuk keperluan penting keluarga lainnya.

\section{D.1 Menambah Penghasilan Suami dan Pendapatan Keluarga}

Usaha ekonomi sektor informal berupa penjualan makanan, minuman, dan pelayanan jasa yang dilakukan oleh kaum perempuan di kawasan Wisata Bahari Pantai Batu Gong, menguntungkan kaum perempuan sehingga pendapatan yang mereka peroleh dapat berperan menambah penghasilan suami dan juga menambah penghasilan keluarga. Pernyataan tersebut sebagaimana dikatakan oleh informan penelitian yang bernama Nurma (32 tahun), pendidikan Sekolah Dasar, Agama Islam, dengan jumlah tanggungan keluarga sebanyak 3 orang anak. Usaha ekonomi yang dilakukan adalah menyewakan ban dalam (pelampung untuk alat bantu berenang pengunjung), menjual makanan tradisional berupa sate pokea dan gogos, serta menjual aneka jenis minuman. Pendapatan sekitar Rp 950.000 (Sembilan ratus lima puluh ribu rupiah) sampai dengan Rp.1.500.000 (satu juta lima ratus ribu rupiah) per bulan. Berikut kutipan wawancara dengan informan penelitian: "Kami sangat bahagia dan senang karena dapat bekerja dan memperoleh uang, dan bagi saya usaha ini bisa menjadi tumpuan pemenuhan ekonomi, termasuk sebagian besar keluarga yang tinggal di desa ini”.

Pernyataan informan tersebut di atas menunjukkan bahwa aktivitas ekonomi kaum perempuan dalam menjual dan melayani berbagai kebutuhan wisatawan yang berkunjung ke lokasi Wisata Bahari Pantai Batu Gong, merupakan sumber penghasilan yang dapat digunakan untuk memenuhi kebutuhan ekonomi keluarganya. Pembangunan tempat wisata telah merubah kondisi tingkat pendapatan sebagian besar keluarga di Desa Lalimbue yang mana mereka mampu memanfaatkan peluang usaha untuk melakukan usaha ekonomi untuk memperoleh penghasilan dalam rangka memenuhi kebutuhan ekonomi keluarga.

Tanggapan suami dan atau keluarga dari perempuan yang bekerja cukup beragam, namun tanggapan mereka bersifat positif dalam artian mereka setuju, mendukung, dan tidak merasa keberatan jika isteri mereka bekerja. Terkait dengan tanggapan pihak suami atau keluarga dari perempuan yang bekerja di kawasan wisata Bahari Pantai Batu Gong, dapat disimak dari kutipan wawancara dengan salah seorang informan penelitian berikut ini:

"Saya ada punya isteri yang bekerja di tempat ini. Yang sana itu pak, namanya Nurma. Dia sudah lima tahun bekerja di sini. Dia jual-jual macam-macam di sini. Dia jual makanan, minuman, menyewakan tikar, dan menyewakan ban dalam mobil untuk pengunjung, untuk alat bantu berenang. Jujur saya sangat senang dia bisa bekerja dan mempunyai penghasilan sendiri. Lumayan pak, membantu saya. Penghasilan isteri saya satu hari berkisar antara Rp 20.000 sampai Rp. 50.000. Tergantung ramainya pengunjung. Ya dia bisa bantu-bantu saya juga. Kami berdua bekerja sama-sama cari uang. Tapi pendapatan saya sedikit pak, kadang tidak cukup untuk keperluan belanja keluarga, makanya 
dengan bekerjanya isteri saya, saya merasa ikut terbantu (Wawancara dengan Hendri, 37 tahun)".

Berdasarkan pada hasil wawancara dapat diketahui bahwa tanggapan suami dan atau anggota keluarga dari perempuan yang bekerja sangat positif. Tidak ada penolakan atau perasaan keberatan dari seorang suami jika isteri mereka bekerja di luar rumah. Malah yang terjadi sebaliknya yaitu justru para suami dan atau anggota keluarga dari perempuan yang bekerja merasa senang. Isteri bekerja membantu suami untuk memenuhi kebutuhan rumah tangga sehari-hari. Tidak ada konflik dan atau pertengkaran antara suami dan isteri disebabkan oleh karena isteri yang bekerja. Pertengkaran suami isteri tidak terjadi, dan rumah tangga perempuan yang bekerja tetap terjaga dan harmonis. Hal ini disebabkan karena isteri yang bekerja dan mempunyai anak, masih bisa mengatur dan mengelola rumah tangganya, mengurus anak-anak, dan pekerjaan rumah tangga lainnya.

Melalui aktivitas ekonomi kaum perempuan yang membuka usaha di lokasi wisata Bahari Pantai Gong, dari usaha ekonomi tersebut kemudian perempuan memperoleh penghasilan sendiri, secara otomatis akan menambah penghasilan dan meningkatkan pendapatan keluarga. Kondisi semacam ini akan melahirkan kemandirian kaum perempuan serta berakibat pada berkurangnya ketergantungan ekonomi kaum perempuan terhadap suami. Hal ini dapat merubah bentuk relasi suami-isteri dari pola hubungan yang semula bersifat relasi subordinat dan superordinat (hubungan yang bersifat vertikal-dominatif) berubah menjadi pola hubungan yang bersifat horizontalsetara dan pola hubungan kemitraan.

\section{D.2 Keperluan Belanja Kebutuhan Keluarga Sehari-hari}

Dalam sebuah rumah tangga, seorang suami dituntut untuk memenuhi kebutuhan pokok hidup keluarga sehari-hari. Seorang suami yang telah berkeluarga (beristeri dan memiliki anak) mempunyai kewajiban untuk memenuhi kebutuhan pokok isteri dan anak-anaknya. Kebutuhan pokok utama sehari-hari dimaksud seperti kebutuhan sandang, pangan, papan, kesehatan, pendidikan, dan lain-lain. Namun terkadang, dalam kenyataan seorang suami tidak dapat memenuhi kebutuhan keluarganya disebabkan oleh faktor kurangnya penghasilan yang diperoleh suami, atau dapat juga disebabkan oleh karena jenis pekerjaan yang dilakukan oleh seorang suami tidak dapat menghasilkan uang yang cukup banyak untuk membiayai belanja keluarga. Dalam keadaan kekurangan dan keterbatasan pendapatan tersebut, mendorong isteri untuk membantu suami bekerja untuk menambah pendapatan keluarga dan memenuhi kebutuhan rumah tangga. Hal tersebut sebagaimana dikemukakan oleh informan yang bernama Sri Utami (27 tahun), pendidikan lulusan Sekolah Lanjutan Tingkat Atas, beragama Islam dan mempunyai 1 orang anak. Ia menekuni usaha menjual sate pokea dan gogos selama lima tahun dengan pendapatan sekitar Rp 500.000 (Lima ratus ribu rupah) sampai dengan Rp 750.000 (Tujuh ratus lima puluh ribu rupiah) per bulan, sebagaimana diungkapkan dalam wawancara berikut ini:

"Saya pak dan teman-teman perempuan saya, kami banyak di sini ini semua mencari dan berusaha. Seperti saya pak, saya menjual sate dan gogos, ibu-ibu yang lain ada yang menjual makanan, minuman-minuman seperti kopi, teh; ada juga ibu-ibu yang menjual rokok, permen-permen, kacang goreng, kacang rebus; ada juga ibu-ibu yang menjual kue-kue, menyewakan ban, pokoknya banyak sekali macamnya pak, Bapak bisa lihat sendiri mereka. Sejak lokasi wisata 
pantai ini dibuka untuk umum, banyak pengunjung yang datang ke sini. Karena itu kami berinisiatif untuk menjual-jual. Pendapatan kami di sini macam-macam pak, tergantung dari banyak-ramainya pengunjung, dan banyaknya kami laku. Pendapatan saya satu bulan tidak menentu, tapi berkisar antara Rp 500.000-Rp 750.000 per bulan. Uang yang kami dapat tersebut digunakan untuk membantu suami, untuk keperluan belanja rumah tangga dan untuk memenuhi kebutuhan rumah tangga. Saya senang bisa bekerja membantu suami dan memenuhi belanja keluarga sehari-hari.

Berdasarkan pada hasil wawancara dapat diketahui bahwa motivasi dan tujuan dari kaum perempuan ibu-ibu rumah tangga yang bekerja sebagai penjual sate pokea, gogos, air mineral, dan penyedia jasa (sewa ban dalam untuk alat bantu berenang dan sewa tikar) bagi para pengunjung di tempat wisata Bahari Pantai Batu Gong di Desa Lalimbue Kecamatan Bondoala Kabupaten Konawe adalah alasan utama mereka adalah kebanyakan alasan ekonomi. Dalam hal ini mereka bekerja di samping untuk membantu suami yang bekerja dimana penghasilan suami mereka pas-pasan, juga karena perempuan ibu-ibu rumah tangga tersebut bekerja untuk memenuhi kebutuhan ekonomi keluarga, dan untuk memenuhi kebutuhan belanja keluarga sehari-hari lainnya.

Di samping faktor kekurangan dan keterbatasan pendapatan yang diperoleh oleh suami, juga karena faktor tuntutan kebutuhan hidup sehari-hari yang terus meningkat, keadaan inilah yang mendorong para perempuan ibu-ibu rumah tangga ini berinisatif mandiri dan bekerja di sektor publik. Di tempat yang lain, kondisi serupa mendorong kaum perempuan bekerja, ada yang bekerja sebagai buruh tani dan nelayan, ada yang menanam sayur sebagai pekerjaan alternatif. Mereka menanam sayur, kunyit, jahe dan pisang. Hasilnya lumayan memuaskan, karena setiap bulan selalu ada sayur yang dipanen dan terkadang sebagian di jual di pasar. Paling tidak mereka tidak lagi membeli sayur untuk memasak, sebab tinggal memetik saja di pekarangan rumah. Semua upaya yang dilakukan oleh kaum perempaun tersebut di samping untuk membantu suami, memenuhi kebutuhan rumah tangga, juga untuk mempertahankan eksistensi dan kelangsungan hidup keluarga. Pada akhirnya tetap kokoh dan bertahannya sebuah rumah tangga keluarga bukan hanya tanggung jawab suami semata, tetapi juga isteri. Karena itu, peran dan tanggung jawab perempuan sebagai isteri dan ibu rumah tangga semakin besar, perempuan tidak hanya identik dengan kata "sumur, dapur, dan kasur" tetapi juga dapat berperan lebih besar di sektor publik.

\section{D.3 Keperluan Biaya Sekolah Anak}

Budaya dan adat istiadat perdesaan terkait perempuan selalu dikonotasikan sebagai manusia pekerja domestik (homemaker) yang dinilai tidak dapat berkontribusi secara aktif di luar rumah sehingga perannya tidak lebih dari sekadar aktivitas dalam rumah. Perempuan dianggap tidak pantas memimpin dalam pekerjaan karena dinilai sebagai makhluk yang terlalu menggunakan perasaan dan sulit mengambil keputusan dengan bijak.

Pendapat di atas tidak selamanya benar, karena faktanya kita dapat menjumpai di daerah perkotaan dan perdesaan, jamak ditemukan perempuan yang berjuang dan bekerja di sektor publik di luar rumah, utamanya di sektot informal, untuk membantu perekonomian rumah tangga, termasuk perempuan bekerja untuk membiayai pendidikan anak-anaknya. 
Seiring dengan kemajuan zaman dan perkembangan masyarakat, kaum perempuan telah terlibat penuh dan mempunyai peran yang sama penting dengan suami untuk memperbaiki kehidupan anak-anaknya, sehingga anak-anak mereka kelak memiliki kehidupan dan kemampuan ekonomi yang lebih baik, dan salah satu faktor untuk mencapai kehidupan dan masa depan yang lebih baik tersebut adalah melalui pendidikan. Kesadaran dan peran perempuan terhadap pentingnya pendidikan anakanaknya sebagaimana diutarakan oleh informan penelitian.

Sebagai contoh kasus, misalnya ibu-ibu penjual sate pokea, lontong, gogos, mie siram, rokok, minuman, makanan ringan, snack, dan permen. Meskipun mereka hanya menjual dan menjajakan jualan kaki lima, tetapi mereka optimistik dengan masa depan anak-anaknya. Dengan penghasilan pas-pasan, yaitu sekitar Rp 900.000 (Sembilan ratus ribu) per bulan, tetapi dia berusaha menyisihkan sebagian pendapatannya untuk biaya sekolah anak-anaknya. "Saya suruh dan paksa anak-anak saya untuk bersekolah agar hidup mereka tidak susah dan lebih baik dari saya. Biar saya capek, saya rela kerja apa saja yang penting halal demi sekolah anak-anak saya. Kalau mereka mau belajar dan sekolah, berarti ada masa depan.

Kutipan wawancara tersebut di atas menunjukkan bahwa betapa kaum perempuan mempunyai kepekaan dan keperdulian yang tinggi terhadap pendidikan anak-anaknya. Meskipun hari-hari mereka capek bekerja dan bersusah payah menjajakan jualan mereka, bahkan berjalan kaki hingga puluhan kilo meter jauhnya, namun mereka "rela" melakukan semua pekerjaan itu demi sekolah, pendidikan, dan masa depan anakanaknya. Kaum perempuan, ibu-ibu rumah tangga ini sadar betul bahwa pendidikan merupakan tangga, media, dan sarana paling logis dan realistik untuk mencapai kehidupan yang lebih baik dan mencapai masa depan yang cerah. Sebagaimana dikatakan oleh Haryatmoko ${ }^{16}$ bahwa sekolah diandalkan sebagai tempat efektif untuk menaiki jenjang sosial (social mobility). Melalui sekolah orang berharap akan memperbaiki kehidupannya baik secara ekonomi, sosial, budaya maupun posisi dalam hierarki sosial. Imajinasi republikan Perancis mengembangkan gambaran mobilitas sosial dalam tiga generasi: kakek petani, orangtua guru, anak menjadi intelektual (penulis), pemimpin perusahaan atau pejabat. Dengan demikian, sekolah juga merupakan media untuk meningkatkan status sosial ekonomi keluarga. Keberhasilan pendidikan anak di masa depan dapat membuka peluang terjadinya mobilitas sosial vertikal (vertical social mobility) bagi anak dan keluarga.

\section{D.4 Ditabung Untuk Keperluan Penting Keluarga Lainnya}

Penghasilan perempuan ibu rumah tangga yang bekerja, di samping menambah penghasilan suami dan keluarga, keperluan belanja kebutuhan keluarga sehari-hari, keperluan biaya sekolah anak, juga dapat digunakan untuk biaya kesehatan, membeli perhiasan, dan ditabung.

"Kalau saya tidak menabung, kasian kalau ada keperluan mendesak, ke mana lagi saya harus meminjam uang?" Pernyataan tersebut merupakan kutipan wawancara dari salah seorang informan penelitian. Ibu-ibu rumah tangga yang menjual di kawasan Wisata Bahari Pantai Batu Gong ini mempunyai kesadaran akan pentingnya dan keutamaan menabung atau menyimpan sebagian uang. Kepandaian perempuan dalam menyimpan uang ini sekaligus merupakan kepandaian dalam mengelola ekonomi rumah tangga. Bahwa suatu saat nanti akan tiba waktunya di mana kita sebagai keluarga rumah

${ }^{16}$ Haryatmoko, Sekolah: Untuk Semua atau Alat Seleksi Sosial? Reproduksi Kesenjangan Sosial Lewat Sekolah Perspektif Pierre Bourdieu, (Yogyakarta: Jurusan Sosiologi FISIPOL UGM, 2008). 
tangga akan mengalami yang namanya "masa krisis" atau masa kekurangan uang, baik kekurangan yang disebabkan oleh kebutuhan yang mendesak yang membutuhkan pemenuhan segera seperti biaya musibah, biaya sakit untuk berobat (kesehatan), biaya sekolah, biaya sosial, dan biaya untuk kebutuhan-kebutuhan penting lainnya.

Tabungan adalah simpanan uang yang sangat membantu keluarga rumah tangga terutama ketika keluarga mengalami yang namanya krisis dan bencana. Dalam banyak kasus, perempuan lebih "bisa" menyimpan uang ketimbang laki-laki. Dari sekian bukti yang bisa dirujuk antara lain misalnya Muhammad Yunus ${ }^{17}$, lebih percaya kepada ibuibu dan perempuan miskin untuk diberikan pinjaman sebagi modal usaha di India, sampai akhirnya Muhammad Yunus bersama ibu-ibu berhasil mendirikan Grameen Bank di India.

Demikian pula Pemerintah Republik Indonesia melalui Kementerian Sosial dalam program bantuan sosial, yaitu Program Keluarga Harapan (PKH) lebih percaya sehingga memberikan kepada ibu-ibu yang menerima bantuan pencairan uang tunai PKH ketimbang laki-laki ${ }^{18}$. Spirit Nabi Yusuf AS ada pada diri kaum perempuan, bahwa Nabi Yusuf AS mampu menyelamatkan negeri Mesir dari krisis dan bencana besar berupa kekeringan dan kelaparan berkepanjangan. Berkat kepintaran dan kecerdasan Nabi Yusuf AS dalam menyimpan dan mengelola harta kekayaan negeri Mesir, maka ketika terjadi "masa krisis dan masa kekeringan yang berkepanjangan", Nabi Yusuf AS mampu menyelamatkan rakyat Mesir dari bahaya kelaparan dan kemiskinan.

Tulisan ini menegaskan bahwa peran perempuan yang bekerja di luar rumah sektor publik sangat besar. Para perempuan yang bekerja ini ingin merubah pemikiran masyarakat yang sudah terlanjur tertanam selama ini bahwa perempuan secara ekonomi tidak memberikan kontribusi bagi keluarga. Masalah ekonomi adalah tanggung jawab suami. Selama ini perempuan dilekatkan dengan "sumur, dapur dan kasur", namun seiring dengan perkembangan zaman, stereotipe tersebut sudah mulai bergeser. Peran perempuan yang dahulu hanya berkaitan dengan sektor domestik, sekarang telah bergeser ke sektor publik. Hal ini sejak awal 1900-an sudah disuarakan oleh RA Kartini bahwa kaum perempuan harus bangkit dari sektor domestik ke sektor publik.

\section{E. Penutup}

Memerangi ketidakadilan sosial sepanjang sejarah kemanusiaan, selalu menjadi tema menarik dan tetap akan menjadi tema penting dalam setiap pemikiran dan konsepsi kemasyarakatan di masa mendatang, termasuk tema ketidakadilan terhadap perempuan. Perjuangan ketidakadilan terhadap kaum perempuan dimulai sejak era Kartini. Kartini telah berjuang untuk membebaskan kaum perempuan dari diskriminasi gender. Kaum perempuan tidak hanya bekerja mengurus anak di rumah, tetapi juga bisa bekerja di sektor publik.

Aktivitas domestik sudah sejak lama dilekatkan pada perempuan dan ini telah membudaya. Perempuan selalu dikonotasikan sebagai manusia pekerja domestik (homemaker) yang dinilai tidak dapat berkontribusi secara aktif di luar rumah sehingga perannya tidak lebih dari sekadar aktivitas dalam rumah. Wacana tersebut dinilai

\footnotetext{
${ }^{17}$ Yunus, Muhammad, Bank Kaum Miskin: Kisah Yunus dan Grameen Bank Memerangi Kemiskinan, (Depok: Marjin Kiri, 2007).

18 Tuwu, Darmin, "Efektivitas Implementasi Program Keluarga Harapan Untuk Menanggulangi Kemiskinan Di Kota Kendari". Makalah Dipresentasikan Dalam "Konferensi Nasional dan Kongres Asosiasi Pendidikan Kesejahteraan Sosial dan Pekerjaan Sosial Indonesia Ke-IX” Tanggal 12 - 13 April 2018 di STISIPOL Candradimuka Palembang.
} 
sebagai wacana usang yang tidak dapat dibuktikan secara nyata, karena banyak perempuan telah mengambil bagian penting di ranah produktif.

Hasil penelitan ini paling tidak dapat menjadi bukti penting bahwa peran perempuan di ranah publik semakin mengemuka. Peran perempuan Desa Lalimbue semakin besar dengan berinisiatif membuka usaha ekonomi dengan memanfaatkan peluang bisnis di kawasan Wisata Bahari Pantai Batu Gong. Meskipun kiprah perempuan baru sebatas usaha ekonomi sektor informal, namun upaya tersebut patut diapresiasi karena perempuan mau berusaha dan bangkit bekerja di luar rumah untuk membantu ekonomi rumah tangga dan meningkatkan kesejahteraan keluarga.

Pada masa mendatang, peran perempuan di sektor publik agar lebih dikedepankan lagi dengan memasuki peluang usaha lebih banyak lagi, tidak hanya bekerja di sektor informal tetapi juga dapat bekerja di tempat strategis seperti di sektor formal pemerintahan. Dengan demikian, kesejahteraan keluarga dapat diwujudkan.

\section{Daftar Pustaka}

Sayogyo. "Pemikiran tentang Kemiskinan di Indonesia: Dari Masa Penjajahan Sampai Masa Pembangunan". Prisma: Majalah Pemikiran Politik, Sosial dan Ekonomi. Nomor 3, (Tahun XII, 1993).

Ken, Suratiyah, dkk. Dilema Wanita Antara Industri Rumah Tangga dan Aktivitas Domestik. Yogyakarta: Aditya Media, 1996.

Sajogyo, Pudjiwati. Peranan Wanita Dalam Pembangunan Masyarakat Desa. Jakarta: Rajawali Pers, 1983.

Kesselmen, Amy dkk. Women Images and Realities, A Multicultural Anthology, Second Edition. California: Mayfield Publishing Company, 1999.

Fakih, Mansour. Analisis Gender dan Transformasi Sosial. Yogyakarta: Pustaka Pelajar Offset, 2007.

Saptari, Ratna, dan Holzner Brigitte. Perempuan Kerja dan Perubahan Sosial; Sebuah Pengantar Studi Perempuan. Jakarta: Kalyanitra, 1997.

Budiman, Manneke. "Bapak Rumah Tangga: Menciptakan Kesetaraan atau Membangun Mitos Baru?”. Jurnal Perempuan. Volume 18 No. 1, (Maret, 2013): 79-92.

Candraningrum, Dewi. "Superwoman Syndrome dan Devaluasi Usia: Perempuan dalam Karier dan Rumah Tangga”. Jurnal Perempuan. Volume 18 No. 1, (Maret, 2014).

Tuwu, Darmin. "Studi Aspirasi Warga Komunitas Miskin Penambang Batu dan Pemecah Batu Suplit di Kecamatan Moramo Utara Kabupaten Konawe Selatan". Etnoreflika (Jurnal Sosial dan Budaya Jurusan Antropologi FIB UHO). Volume 4, Nomor 1. (Februari, 2015): 702-709.

Irwan, Abdullah. Seks, Gender dan Reproduksi Kekuasaan. Yogyakarta: Tarawang Press, 2001.

Robert K. Yin, Studi Kasus: Desain dan Metode, (Jakarta: PT. RajaGrafindo Persada, 2008. 29.

Sugiyono, Metode Penelitian Kuantitatif Kualitatif Dan $R \& D$. Bandung: Penerbit Alfabeta, 2007.

Haryatmoko. Sekolah: Untuk Semua atau Alat Seleksi Sosial? Reproduksi Kesenjangan Sosial Lewat Sekolah Perspektif Pierre Bourdieu. Yogyakarta: Jurusan Sosiologi FISIPOL UGM, 2008. 
Yunus, Muhammad. Bank Kaum Miskin: Kisah Yunus dan Grameen Bank Memerangi Kemiskinan. Depok: Marjin Kiri, 2007.

Tuwu, Darmin. "Efektivitas Implementasi Program Keluarga Harapan Untuk Menanggulangi Kemiskinan Di Kota Kendari”. Makalah Dipresentasikan Dalam "Konferensi Nasional dan Kongres Asosiasi Pendidikan Kesejahteraan Sosial dan Pekerjaan Sosial Indonesia Ke-IX" Tanggal 12 - 13 April 2018 di STISIPOL Candradimuka Palembang. 